\title{
The consumption of chili peppers and the risk of colorectal cancer: a matched case- control study
}

\author{
Yalan Yang ${ }^{1}$, Jing Zhang ${ }^{2}$, Noel S. Weiss ${ }^{3}$, Linwen Guo ${ }^{1}$, Li Zhang ${ }^{1}$, Yanqi Jiang ${ }^{1}$ and Yanfang Yang ${ }^{1 *}$
}

\begin{abstract}
Background: Chili peppers have properties that plausibly could either increase or decrease a person's risk of developing colorectal cancer, but their consumption in relation to disease risk has not been well studied. We sought to explore the association between chili peppers intake and the risk of colorectal cancer.

Methods: Eight hundred subjects (400 cases with colorectal cancer and 400 controls) were enrolled in this study. Cases were primarily colorectal cancer patients diagnosed by histopathology at the Department of Intestinal Surgery, Sichuan Cancer Hospital from July 2010 to May 2012. Controls were people receiving routine medical examinations from the Zhonghe Community Health Service Center during the same period of time. An in-person interview was used to collect demographic characteristics, lifestyle, and dietary habits of the subjects in reference to the 10 years prior to disease diagnosis. Conditional logistic regression was conducted to examine the possible association between the risk of colorectal cancer and chili peppers consumption.
\end{abstract}

Results: Compared with persons who consumed chili peppers $\leq 2$ times per week, those who consumed chili peppers 3-7 times per week ( $\mathrm{OR}=1.2,95 \% \mathrm{Cl} 0.75-2.0, P=0.413)$ and $>7$ times per week $(\mathrm{OR}=1.4,95 \% \mathrm{Cl} 0.84-2.2, P=0.205)$ were not at an increased risk of colorectal cancer.

Conclusions: The results suggest that the consumption of chili peppers does not increase or decrease the risk of colorectal cancer. This question warrants being re-addressed in a study in which there is prospective ascertainment of dietary characteristics.

Keywords: Colorectal cancer, Chili peppers, Diets, Case-control study

\section{Background}

Colorectal cancer(CRC)is at present the third most common malignancy in the world [1]. Historically, the incidence rates have been different in various countries. With changes in lifestyle and the westernization of dietary habits, the incidence of and mortality from CRC in China have increased in recent years. In 2015, there were 376,000 new cases and 191,000 deaths in China [2].

The chili pepper has been a part of the human diet for thousands of years [3]. It was often used as a main condiment in Sichuan province. The chili pepper contains capsaicinoids, derivatives of phenylpropanoid compounds,

\footnotetext{
* Correspondence: yang2009@scu.edu.cn

${ }^{1}$ Department of Epidemiology and Biostatistics, West China School of Public

Health and West China Fourth Hospital, Sichuan University, Chengdu,

Sichuan, China

Full list of author information is available at the end of the article
}

which are responsible for their intense hot taste and pungency, with E-capsaicin (8-methyl-N-vanillyl-trans-6-nonenamide) being the major capsaicinoid present in chili peppers [4]. A study has been observed that capsaicin can downregulate the expression of COX-2 and B-catenin mRNA, promoting apoptosis through caspase 3 activation and inhibiting the proliferation of cells [5, 6]. However, intake of chili peppers also could act as an irritant, leading to an inflammatory reaction that could favor the development of malignancy. While consumption of chili peppers has been observed to be associated with a reduction in incidence of all forms of cancer combined [7], this question has not been examined specifically for CRC.

(C) The Author(s). 2019 Open Access This article is distributed under the terms of the Creative Commons Attribution 4.0 International License (http://creativecommons.org/licenses/by/4.0/), which permits unrestricted use, distribution, and reproduction in any medium, provided you give appropriate credit to the original author(s) and the source, provide a link to the Creative Commons license, and indicate if changes were made. The Creative Commons Public Domain Dedication waiver (http://creativecommons.org/publicdomain/zero/1.0/) applies to the data made available in this article, unless otherwise stated. 


\section{Objects and methods Study participants}

We made the matching principle before participants recruiting. Controls were matched 1:1 to cases by gender and age ( \pm 3 years). Eight hundred subjects (400 cases with CRC and 400 controls) were enrolled who were (1) Han Chinese and (2) had lived in the province of Sichuan for more than 10 years. We excluded persons with (1) a history of other cancers; (2) a history of digestive system diseases; and (3) several other conditions (i.e., hypertension, diabetes, hyperlipidemia). Cases were primarily CRC patients diagnosed by histopathology at the Department of Intestinal Surgery, Sichuan Cancer Hospital (Chengdu, Sichuan, China) from July 2010 to May 2012. The age of cases was no limit. Controls were people from the Zhonghe Community Health Service Center (Chengdu, Sichuan, China) seen during the same period of time who had no earlier history of cancer. We obtained written informed consent from all subjects. The study protocol was approved by the West China Fourth Hospital of Sichuan University (West China School of Public Health).

\section{Survey}

A face-to-face interview was conducted with subjects. If the patient could not answer the questions, family members were asked to serve as proxy respondents. The interview sought information on demographic characteristics, family history of $\mathrm{CRC}$, and dietary habits and lifestyle characteristics during the 10 years before diagnosis.

Specifically, we asked about consumption of (1) chili peppers; (2) red meat (e.g., beef, lamb, and pork). According to the Dietary Guideline and Balance Diet Pagoda for Chinese Residents, the recommended daily consumption for red meat is $50-75 \mathrm{~g}$ [8]. This study defined the intake amount of $>50 \mathrm{~g}$ as one intake of red meat $[9,10],>7$ times per week being defined as "high" consumption [9]; (3) cured meat (with more than $30 \mathrm{~g}, \geq 24$ times per year being defined as "high" consumption [7]); (4) pickles ( $\geq 3$ times per week being defined as "high" consumption [11]); (5) bean products $(\geq 3$ times per week being defined as "high" consumption [11]); (6) high-fat foods (e.g., animal liver, kidney, brain, large intestine, frequency per month, $>2$ times per month being defined as "high" consumption); (7) sweetmeats (e.g., dessert, candy, ice cream, chocolate, frequency per week, $\geq 3$ times per week being defined as "high" consumption [11]); (8) fruit (frequency per week, $\geq 3$ times per week being defined as "high" consumption [11]); and (9) vegetable (frequency per week, > 7 times per week being defined as "high" consumption [11]).

We also asked study participants about smoking regularly (smoking more than one cigarette per day for at least 6 months [12]), drinking alcohol regularly (drinking one time per day or more and drinking for a month or more [13]), tea-drinking regularly (drinking tea one time per day or more and drinking for a month or more [14]), and exercise regularly (weekly exercise $\geq 3$ times for $\geq 20 \min [11]$ ).

\section{Statistical analysis}

EpiData 3.1 software and SPSS 22.0 software were used for statistical analysis. Referring to the classification of dietary factors in other studies [9], Chili peppers were classified according to four-digit intervals (the upper quartile and the lower quartile) of per week consumption. Other diets and lifestyle were all classified referring to the previous researches of our group $[9,11]$. The odds ratios (OR) with 95\% confidence intervals (CI) for chili pepper in CRC risk were calculated using conditional logistic regression (LR) and adjusted by other diets and lifestyle. Some factors were determined as the adjustments based on their $P$ value $(P<0.05)$. Other factors were identified as the adjustments because they were mostly thought to be related to CRC in other studies. The significance level was $P<0.05$.

\section{Results}

\section{Characteristics of participants}

For the cases and controls, 233 (58.2\%) were males and 167 (41.8\%) were females. The mean ages were $55.73 \pm$ 11.08 years old in the cases and $55.74 \pm 11.19$ years old in the controls. There were no significant differences in education, profession, and household per capita annual income between cases and controls $(P>0.05)$. Demographic characteristics of cases and controls are presented in Table 1.

\section{Diets and lifestyle}

In Table 2, we present the distribution of consumption of all diets and lifestyle in cases and controls: chili peppers, red meat, cured meat, pickles, tea, beans, fruits, vegetable, and sweetmeats, as well as their distributions with respect to lifestyle and a family history of CRC. There were significant differences in the distribution of chili peppers, red meat, cured meat, pickles, tea-drinking regularly, beans, fruit, sweetmeats, daily sitting time, exercise regularly, and family history of CRC between the cases and controls $(P<0.05)$.

Table 3 presents the results of a multivariate analysis of chili peppers in relation to CRC in which we adjusted for consumption of red meat, cured meat, pickles, tea, beans, fruit, vegetables, high-fat foods, sweetmeats; and for daily sitting time, smoking regularly, drinking regularly, exercise regularly, and family history of CRC. There were significant differences among red meat, cured meat, pickles, tea, bean, daily sitting time, exercise regularly, and family history of CRC $(P<0.05)$. However, there were no significant differences among chili peppers, fruit, vegetables, high-fat food, sweetmeats, 
Table 1 Distribution of demographic characteristics between cases and controls

\begin{tabular}{|c|c|c|c|c|}
\hline Variables & Cases $N(\%)$ & Controls $N(\%)$ & $x^{2}$ & $P$ \\
\hline \multicolumn{5}{|l|}{ Education } \\
\hline Primary school and below & $151(37.75)$ & 175(43.75) & 5.576 & 0.062 \\
\hline Junior-senior high school and secondary school & $216(54.00)$ & 183(45.75) & & \\
\hline Junior college and above & $33(8.25)$ & $42(10.50)$ & & \\
\hline \multicolumn{5}{|l|}{ Profession } \\
\hline Enterprises and institutions & 104(26.00) & $111(27.75)$ & 1.287 & 0.864 \\
\hline Manufacturing industry & $78(19.50)$ & $85(21.25)$ & & \\
\hline Transport industry & $12(3.00)$ & $13(3.25)$ & & \\
\hline Agriculture, forestry, fishery, and animal husbandry & $145(36.25)$ & 131(32.75) & & \\
\hline Others & $61(15.25)$ & $60(15.00)$ & & \\
\hline \multicolumn{5}{|l|}{ Household per capita annual income(yuan per year) } \\
\hline$<10000$ & 134(33.50) & 118(29.50) & 1.530 & 0.465 \\
\hline $10000-20000$ & 159(39.75) & $166(41.50)$ & & \\
\hline$>20000$ & $107(26.75)$ & $116(29.00)$ & & \\
\hline
\end{tabular}

smoking regularly, and drinking regularly $(P>0.05)$. We observed that weekly consumption of chili peppers 3 to 7 times $(\mathrm{OR}=1.295 \%$ CI $0.75-2.0)$ and $>7$ times (OR $=1.495 \% \mathrm{CI} 0.84-2.2)$ were not associated with the risk of CRC. (Table 3)

Table 4 presents the ORs associated with intake of chili peppers in different subgroups defined by intake of red meat, cured meat, high-fat foods; daily sitting time; smoking regularly, and drinking regularly. Across these subgroups, generally, there was no association between the consumption of chili peppers and the risk of $\mathrm{CRC}(P$ $>0.05)$. There was one possible exception; among persons with a relatively low consumption of cured meat, we observed an increased risk associated with weekly consumption of chili peppers 3-7 times $(\mathrm{OR}=1.295 \%$ CI $0.78-2.0)$ and $>7$ times $(\mathrm{OR}=1.695 \%$ CI $1.1-2.5)$, whereas no such increases were seen among persons with a relatively high consumption of cured meat.

\section{Discussion}

Capsaicin concentration is related to the variety and maturity of chili peppers and its concentration can change. E-capsaicin is the major capsaicin in chili peppers. A study shows a greater than 25-fold variation in E-capsaicin levels among individual peppers, ranging from about $0.04 \mu \mathrm{g} /$ $\mathrm{mL}$ to $1 \mu \mathrm{g} / \mathrm{mL}$ [15]. In general, the concentration of capsaicin ranges from 0.1 to $1 \%$ in chili peppers.

The results of some studies suggested that intake of capsaicin may predispose to one or more forms of gastrointestinal cancer. Dietary administration of capsaicin produced duodenal tumors in Swiss albino mice [16]. An epidemiological study conducted in Mexico observed that consumers of chili peppers were at higher risk for gastric cancer than non-consumers [17]. In addition, excessive consumption of chili peppers may irritate colonic mucosa. Ingestion of large amounts of capsaicin has been reported to cause histopathological and biochemical changes, including erosion of gastric mucosa and hepatic necrosis [18].

However, the results of other studies suggested that intake of capsaicin might reduce cancer risk. Studies in the laboratory had observed capsaicin to interfere with the action of some chemical carcinogens, such as aflatoxin $B_{1}$ and the tobacco-specific nitrosamine, 4-(methylnitrosamino)-1-(3-pyridyl)-1-butanone [19], and also to inhibit the proliferation of CRC cells and induce apoptosis and necrosis of cancer cells.

Initial work by Hoch-Ligeti showed that rats fed diets containing 10\% chili pepper developed liver tumors [20]. The validity of this study, however, was questioned because of possible contamination of the experimental diet with the potent hepatocarcinogen aflatoxin $B_{1}$. Results of Surh and Lee's preliminary study indicated that repeated application of capsaicin on the shaved backs of female ICR mice following an initial dose of 7,12-dimethylben-

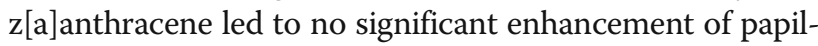
loma formation in the skin, compared with the control animals that received the carcinogen alone. Summarizing the relevant studies, Surh and Lee suggested that although a minute amount of capsaicin displays few or no deleterious effects, heavy ingestion of the compound has been associated with necrosis, ulceration, and even carcinogenesis [18]. According to previous studies, capsaicin has both carcinogenic and anticancer effects.

In our study, we did not observe a significant difference in chili peppers: compared to persons consuming chili peppers no more than twice each week, the relative risk in those whose weekly intake was 3-7 times and $>7$ times 
Table 2 Distribution of dietary and lifestyle characteristics of cases and controls

\begin{tabular}{ccccc}
\hline Variables & Cases, N(\%) & Controls, N(\%) & $x^{2}$ & $P$ \\
\hline \multicolumn{2}{l}{ Chili peppers (times per week) } & & & \\
$\leq 2$ & $95(23.75)$ & $136(34.00)$ & $17.601^{\mathrm{a}}$ & $<0.001$ \\
$3-7$ & $114(28.50)$ & $130(32.50)$ & & \\
$>7$ & $191(47.75)$ & $134(33.50)$ & &
\end{tabular}

Red meat(times per week)

$$
\begin{array}{ll}
\leq 7 & 144(36.00) \\
>7 & 256(64.00)
\end{array}
$$

214(53.50)

$24.773<0.001$

Cured meat(times per year)

$\begin{array}{lllll}<24 & 144(36.00) & 240(60.00) & 46.154 & <0.001 \\ \geq 24 & 256(64.00) & 160(40.00) & & \end{array}$

Pickles(times per week)

$\begin{array}{lll}<3 & 151(37.75) & 259(64.75) \\ \geq 3 & 249(62.25) & 141(35.25)\end{array}$

Tea-drinking regularly

$\begin{array}{lll}\text { No } & 249(62.25) & 211(52.75) \\ \text { Yes } & 151(37.75) & 189(47.25)\end{array}$

Beans(times per week)

$\begin{array}{lll}<3 & 318(79.50) & 271(67.75) \\ \geq 3 & 82(20.50) & 129(32.25)\end{array}$

Fruits(times per week)

$$
<3 \quad 186(46.50)
$$$$
\text { 150(37.50) }
$$$$
\geq 3 \quad 214(53.50)
$$

250(62.50)

High-fat food(times per week)

$$
\begin{array}{ll}
\leq 2 & 273(68.25) \\
>2 & 127(31.75)
\end{array}
$$

282(70.50)

118(29.50)

Sweetmeats(times per week)

$$
\begin{array}{lll}
<3 & 296(74.00) & 323(80.75) \\
\geq 3 & 104(26.00) & 77(19.25)
\end{array}
$$

Vegetables(times per week)

$$
\begin{array}{lll}
\leq 7 & 56(14.00) & 61(15.25) \\
>7 & 344(86.00) & 339(84.75)
\end{array}
$$

Daily sitting time(hour)

$$
\begin{array}{ll}
<8 & 296(74.00) \\
\geq 8 & 104(26.00)
\end{array}
$$

$337(84.25)$

63(15.75)

Smoking regularly

$$
\begin{array}{ll}
\text { No } & 226(56.50) \\
\text { Yes } & 174(43.50)
\end{array}
$$

Drinking regularly

$$
\begin{array}{ll}
\text { No } & 273(68.25) \\
\text { Yes } & 127(31.75)
\end{array}
$$

Exercise regularly

$\begin{array}{lll}\text { No } & 247(61.75) & 151(37.75) \\ \text { Yes } & \text { 153(38.25) } & \text { 249(62.25) }\end{array}$

Table 2 Distribution of dietary and lifestyle characteristics of cases and controls (Continued)

\begin{tabular}{lllll}
\hline Variables & Cases, $N(\%)$ & Controls, $N(\%)$ & $X^{2}$ & $P$ \\
\hline Family history of CRC & & & \\
No & $365(91.25)$ & $391(97.75)$ & 16.258 & $<0.001$ \\
Yes & $35(8.75)$ & $9(2.25)$ & & \\
\hline
\end{tabular}

was 1.2 (95\% CI $0.75-2.0)$ and 1.4 (95\% CI 0.84-2.2), respectively. In fact, the relationship between chili peppers and CRC was indeed complex. The chili pepper is a spicy food, and excess consumption may damage to colonic mucosa. The long-term damage is related to the occurrence of CRC. In addition, capsaicin may play the weak carcinogenesis role in causing CRC. In another context, chili peppers are beneficial. Capsaicin also has an anticancer effect. Besides, ingestion of chili peppers can promote digestive juice to secrete and accelerate bowel movements [21], which may reduce the risk of CRC.

Generally, there was little difference in the size of the OR associated with consumption of chili peppers across different subgroups, though we did observe an increased risk associated with weekly consumption of chili peppers 3-7 times (OR $=1.295 \%$ CI 0.78-2.0) and $>7$ times (OR $=1.695 \%$ CI 1.1-2.5) among persons with a relatively low consumption of cured meat. With our existing knowledge, we considered it suggested a link or an interaction between chili pepper and cured meat. Lots of capsaicin may weakly suppress the chemical carcinogens, such as PAH found in cured meat. It needs further study to elucidate the mechanism associated with this observation.

Interpretation of the results must take into account some limitations of our study. First, family members responding to proxy respondents about diet habits over the past 10 years is a limitation. And the study collected dietary information only for the past 10 years, which may be less relevant to risk than intake earlier in life. Second, even for intake during the past 10 years, there can be non-differential misclassification of exposure status when interviews are used to obtain the information on frequency of intake. Third, the study measured only the times of chili

Table 3 ORs and 95\%Cls of chili peppers for CRC

\begin{tabular}{lllll}
\hline Variable & Cases N(\%) & Controls N(\%) & $\mathrm{OR}^{\mathrm{a}}(95 \% \mathrm{Cl})$ & $P$ \\
\hline $\begin{array}{l}\text { Chili peppers } \\
\text { (times per week) }\end{array}$ & & & & \\
$\leq 2$ & $95(23.75)$ & $136(34.00)$ & Reference & \\
$3-7$ & $114(28.50)$ & $130(32.50)$ & $1.2(0.75-2.0)$ & 0.413 \\
$>7$ & $191(47.75)$ & $134(33.50)$ & $1.4(0.84-2.2)$ & 0.205
\end{tabular}

${ }^{2}$ Adjusted for intake of red meat, cured meat, pickles, tea, bean, fruit, vegetables, high-fat food, and sweetmeats; for daily sitting time, smoking regularly, drinking regularly, and exercise regularly; and for family history of CRC 
Table 4 ORs and 95\% Cls of chili pepper for CRC in different groups

\begin{tabular}{|c|c|c|c|c|c|}
\hline Subgroups & Variable & Cases N(\%) & Controls N(\%) & $\mathrm{OR}(95 \% \mathrm{Cl})$ & $P$ \\
\hline \multirow[t]{4}{*}{$\begin{array}{l}\text { Low red meat } \\
\text { ( } \leq 7 \text { times per week) }\end{array}$} & $\begin{array}{l}\text { Chili peppers } \\
\text { (times per week) }\end{array}$ & & & & \\
\hline & $\leq 2$ & $39(27.08)$ & $88(41.12)$ & Reference & \\
\hline & $3-7$ & 55(38.19) & $80(37.38)$ & $1.0(0.69-1.6)$ & 0.826 \\
\hline & $>7$ & $50(34.72)$ & $46(21.50)$ & $1.3(0.80-2.0)$ & 0.326 \\
\hline \multirow[t]{4}{*}{$\begin{array}{l}\text { High red meat } \\
\text { (> } 7 \text { times per week) }\end{array}$} & $\begin{array}{l}\text { Chili peppers } \\
\text { (times per week) }\end{array}$ & & & & \\
\hline & $\leq 2$ & $56(21.88)$ & $48(25.81)$ & Reference & \\
\hline & $3-7$ & $59(23.05)$ & $50(26.88)$ & $0.96(0.65-1.4)$ & 0.835 \\
\hline & $>7$ & $141(55.08)$ & $88(47.31)$ & $1.1(0.76-1.5)$ & 0.736 \\
\hline \multirow[t]{4}{*}{$\begin{array}{l}\text { Low cured meat } \\
(<24 \text { times per year) }\end{array}$} & $\begin{array}{l}\text { Chili peppers } \\
\text { (times per week) }\end{array}$ & & & & \\
\hline & $\leq 2$ & $36(25.00)$ & $101(42.08)$ & Reference & \\
\hline & $3-7$ & $38(26.39)$ & $78(32.50)$ & $1.2(0.78-2.0)$ & 0.362 \\
\hline & $>7$ & $70(48.61)$ & $61(25.42)$ & $1.6(1.1-2.5)$ & 0.022 \\
\hline \multirow[t]{4}{*}{$\begin{array}{l}\text { High cured meat } \\
(\geq 24 \text { times per year) }\end{array}$} & $\begin{array}{l}\text { Chili peppers } \\
\text { (times per week) }\end{array}$ & & & & \\
\hline & $\leq 2$ & $59(23.05)$ & $35(21.88)$ & Reference & \\
\hline & $3-7$ & $76(29.69)$ & $52(32.50)$ & $0.90(0.63-1.3)$ & 0.539 \\
\hline & $>7$ & $121(47.27)$ & $73(45.63)$ & $0.89(0.65-1.2)$ & 0.499 \\
\hline \multirow[t]{4}{*}{$\begin{array}{l}\text { Low high-fat food } \\
\text { ( } \leq 2 \text { times per week) }\end{array}$} & $\begin{array}{l}\text { Chili peppers } \\
\text { (times per week) }\end{array}$ & & & & \\
\hline & $\leq 2$ & $75(27.47)$ & 104(36.88) & Reference & \\
\hline & $3-7$ & $69(25.27)$ & $87(30.85)$ & 0.98(0.70-1.4) & 0.907 \\
\hline & $>7$ & $129(47.25)$ & $91(32.27)$ & $1.1(0.84-1.5)$ & 0.404 \\
\hline \multirow[t]{4}{*}{$\begin{array}{l}\text { High high-fat food } \\
\text { (>2 times per week) }\end{array}$} & $\begin{array}{l}\text { Chili peppers } \\
\text { (times per week) }\end{array}$ & & & & \\
\hline & $\leq 2$ & 20(15.75) & $32(27.12)$ & Reference & \\
\hline & $3-7$ & $45(35.43)$ & $43(36.44)$ & $1.1(0.65-1.9)$ & 0.700 \\
\hline & $>7$ & $62(48.82)$ & $43(36.44)$ & $1.1(0.66-1.9)$ & 0.666 \\
\hline \multirow[t]{4}{*}{$\begin{array}{l}\text { Low daily sitting } \\
(<8 \mathrm{~h})\end{array}$} & $\begin{array}{l}\text { Chili peppers } \\
\text { (times per week) }\end{array}$ & & & & \\
\hline & $\leq 2$ & $70(23.65)$ & 118(35.01) & Reference & \\
\hline & $3-7$ & $91(30.74)$ & 113(33.53) & $1.1(0.78-1.5)$ & 0.624 \\
\hline & $>7$ & $135(45.61)$ & 106(31.45) & $1.2(0.92-1.7)$ & 0.157 \\
\hline \multirow[t]{4}{*}{$\begin{array}{l}\text { High daily sitting } \\
(\geq 8 \mathrm{~h})\end{array}$} & $\begin{array}{l}\text { Chili peppers } \\
\text { (times per week) }\end{array}$ & & & & \\
\hline & $\leq 2$ & $25(24.04)$ & $18(28.57)$ & Reference & \\
\hline & $3-7$ & $23(22.12)$ & 17(26.98) & $0.98(0.53-1.8)$ & 0.944 \\
\hline & $>7$ & $56(53.85)$ & $28(44.44)$ & $0.95(0.57-1.6)$ & 0.852 \\
\hline \multirow[t]{4}{*}{ Not regular drinking } & $\begin{array}{l}\text { Chili peppers } \\
\text { (times per week) }\end{array}$ & & & & \\
\hline & $\leq 2$ & $69(25.27)$ & 105(38.32) & Reference & \\
\hline & $3-7$ & $84(30.77)$ & $95(34.67)$ & $1.1(0.76-1.5)$ & 0.761 \\
\hline & $>7$ & $120(43.96)$ & $74(27.01)$ & $1.2(0.88-1.6)$ & 0.262 \\
\hline \multirow[t]{2}{*}{ Regular drinking } & $\begin{array}{l}\text { Chili peppers } \\
\text { (times per week) }\end{array}$ & & & & \\
\hline & $\leq 2$ & $26(20.47)$ & $31(24.60)$ & Reference & \\
\hline
\end{tabular}


Table 4 ORs and 95\% Cls of chili pepper for CRC in different groups (Continued)

\begin{tabular}{|c|c|c|c|c|c|}
\hline Subgroups & Variable & Cases N(\%) & Controls N(\%) & $\mathrm{OR}(95 \% \mathrm{Cl})$ & $P$ \\
\hline & $3-7$ & $30(23.62)$ & $35(27.78)$ & $0.93(0.54-1.6)$ & 0.776 \\
\hline & $>7$ & $71(55.91)$ & $60(47.62)$ & 1.0(0.64-1.6) & 0.922 \\
\hline \multirow[t]{4}{*}{ Not regular smoking } & $\begin{array}{l}\text { Chili peppers } \\
\text { (times per week) }\end{array}$ & & & & \\
\hline & $\leq 2$ & $57(25.22)$ & 88(38.26) & Reference & \\
\hline & $3-7$ & 68(30.09) & $77(33.48)$ & $1.1(0.78-1.6)$ & 0.525 \\
\hline & $>7$ & $101(44.69)$ & $65(28.26)$ & $1.2(0.85-1.7)$ & 0.298 \\
\hline \multirow[t]{4}{*}{ Regular smoking } & $\begin{array}{l}\text { Chili peppers } \\
\text { (times per week) }\end{array}$ & & & & \\
\hline & $\leq 2$ & $38(21.84)$ & 48(28.24) & Reference & \\
\hline & $3-7$ & $46(26.44)$ & $53(31.18)$ & $0.89(0.57-1.4)$ & 0.606 \\
\hline & $>7$ & $90(51.72)$ & $69(40.59)$ & $1.1(0.71-1.6)$ & 0.792 \\
\hline
\end{tabular}

peppers intake, not the quantity consumed. Finally, the referent category used in our analysis included some persons who did consume chili peppers, just at a lower frequency than 3 times per week. However, an analysis in which the referent category has no chili pepper intake could not be done, due to the fact that among the study participants, there was virtually no one who did not consume chili peppers.

\section{Conclusions}

In summary, the results suggest that the consumption of chili peppers does not increase or decrease the risk of CRC. The results of studies with prospective and more detailed ascertainment of diet, in populations (such as this one) in which a high intake of chili peppers is present, are needed to clarify.

\section{Abbreviations}

CRC: Colorectal cancer

\section{Acknowledgements}

Not applicable

\section{Funding}

This study was supported by the National Natural Science Foundation of China (Grant Number 81102196) and the Doctoral Fund of Ministry of Education of China (Grant Number 20090181120019 ).

\section{Availability of data and materials}

All data generated or analyzed during this study are included in this published article.

\section{Authors' contributions}

YYL collected the data, analyzed and interpreted the data, and wrote the manuscript writing. ZJ designed the questionnaire, analyzed the data, and contributed to the manuscript writing. NSW propose research ideas and revise the article. GLW , ZL, and JYQ searched literature and collected the data. YYF designed the study, analyzed and interpreted data, and contributed to the manuscript writing. All authors read and approved the final manuscript.

\section{Ethics approval and consent to participate}

The study protocol was approved by the West China fourth Hospital of Sichuan University (West China School of Public Health).
Consent for publication

Not applicable

\section{Competing interests}

The authors declare that they have no competing interests.

\section{Publisher's Note}

Springer Nature remains neutral with regard to jurisdictional claims in published maps and institutional affiliations.

\section{Author details}

${ }^{1}$ Department of Epidemiology and Biostatistics, West China School of Public Health and West China Fourth Hospital, Sichuan University, Chengdu, Sichuan, China. ${ }^{2}$ Department of Environmental Health and Occupational Medicine, West China School of Public Health and West China Fourth Hospital, Sichuan University, Chengdu, Sichuan, China. ${ }^{3}$ Department of Epidemiology, School of Public Health, University of Washington, Seattle, USA.

Received: 17 December 2018 Accepted: 8 April 2019

Published online: 17 April 2019

\section{References}

1. Siegel RL, Miller KD, Jemal A, et al. Cancer statistics, 2016[J]. CA Cancer JClin. 2016;66(1):7-30

2. Chen W, Zheng R, Baade PD, et al. Cancer statistics in China, 2015[J]. CA Cancer J Clin. 2016;66(2):115-32.

3. Perry L, Dickau R, Zarrillo S, et al. Starch Fossils and the domestication and dispersal of chili peppers (Capsicum spp. L.) in the Americas [J]. Science. 2007;315(5814):986-8.

4. Laskaridoumonnerville A. Determination of capsaicin and dihydrocapsaicin by micellar electrokinetic capillary chromatography and its application to various species of Capsicum, Solanaceae [J]. Journal of Chromatography A. 1999;838(1-2):293-302.

5. Zhang ZH, Han SX, Qiu CH, et al. The mechanism of cell apoptosis in the colorectal cancer induced by capsaicin[J]. Chinese Journal of Gastroenterology and Hepatology. 2014;23(10):1158-61.

6. Yang KM, Pyo JO, Kim GY, et al. Capsaicin induces apoptosis by generating reactive oxygen species and disrupting mitochondrial transmembrane potential in human colon cancer cell lines[J]. Cell Mol Biol Lett. 2009;14(3): 497-510.

7. LV J, Qi L, Yu C, et al. Consumption of spicy foods and total and cause specific mortality: population based cohort study[J]. BMJ (Clinical research ed). 2015:351:h3942 Epub 2015/08/06.

8. Hu XQ, Yuan P, Yan J, et al. Gene Polymorphisms of ADIPOQ +45 T.G, UCP2866G.A, and FABP2 Ala54Thr on the risk of colorectal cancer: a matched case-control Study[J]. PLOS ONE. 2013;8(6):1-8. 
9. Li YL, Fei F, Yan J, et al. Association between cured meat consumption and risk of colorectal cancer in people with different dietary habits and lifestyles[]]. Chin J Epidemiol. 2016;37(7):1006-11.

10. Norat T, Lukanova A, Ferrari P, et al. Meat consumption and colorectal cancer risk: dose-response meta-analysis of epidemiological studies[]]. Int J Cancer. 2002;98(2):241-56.

11. Feng F, Yan J, Yuan P, et al. Relationships between dietary, lifestyle and colorectal cancer: a matched case-control study[]]. Journal of Shandong University (Health Science). 2013;51(7):107-12.

12. Grisso JA, Kelsey JL, O'Brien LA, et al. Risk factors for hip fracture in men[J]. American Journal of Epidemiology. 1997;145(9):786-93.

13. Wang JM, Xu B, Rao JY, et al. Diet habits, alcohol drinking, tobacco smoking, green tea drinking, and the risk of esophageal squamous cell carcinoma in the Chinese population[J]. European journal of gastroenterology \& hepatology. 2007;19(2):171-6.

14. Wu M, Liu AM, Kampman E, et al. Green tea drinking, high tea temperature and esophageal cancer in high- and low-risk areas of Jiangsu Province, China: a population-based case-control study[]]. International journal of cancer. 2009;124(8):1907-13.

15. Welch CJ, Regalado EL, Welch EC, et al. Evaluation of capsaicin in chili peppers and hot sauces by MISER HPLC-ESIMS[]]. Analytical Methods. 2014; 6(3):857-62.

16. Toth B, Gannett P. Carcinogenicity of lifelong administration of capsaicin of hot pepper in mice. In Vivo. 1992;6:59-63.

17. López-Carillo L, Avila MH, Dubrow R. Chili pepper consumption and gastric cancer in Mexico: a case control study. American Journal of Epidemiology. 1994;139:263-71.

18. Surh YJ, Lee SS. Capsaicin in hot chili pepper: Carcinogen, co-carcinogen or anticarcinogen?[J]. Food \& Chemical Toxicology An International Journal Published for the British Industrial Biological Research Association. 1996; 34(3):313-6

19. Teel RW. Effects of phytochemicals on the mutagenicity of the tobacco-specific nitrosamine4-(methylnitrosamino)-I-(3-pyridyl)-I-butanone(NNK) in Salmonella typhimuriurn strain TA1535[]]. Phytotherapy Research. 1993;7:248-51.

20. Hoch-Ligeti C. Naturally occurring dietary agents and their role in production of tumors. Texas Reports on Biology and Medicine. 1952;10(4): 996-1005.

21. Shi MQ. Eating chili peppers should vary with each individual[J]. Journal For Beneficial Veadings Drug Informations \& Medical Advices. 2007;(5):56.

Ready to submit your research? Choose BMC and benefit from:

- fast, convenient online submission

- thorough peer review by experienced researchers in your field

- rapid publication on acceptance

- support for research data, including large and complex data types

- gold Open Access which fosters wider collaboration and increased citations

- maximum visibility for your research: over $100 \mathrm{M}$ website views per year

At $\mathrm{BMC}$, research is always in progress.

Learn more biomedcentral.com/submissions 